Women's Studies

An interdisciplinary journal

ISSN: (Print) (Online) Journal homepage: https://www.tandfonline.com/loi/gwst20

\title{
“Invisible, as Music - ": Sheet Music and Communication in the Dickinson Family
}

\section{Samantha Landau}

To cite this article: Samantha Landau (2021): "Invisible, as Music - ": Sheet Music and Communication in the Dickinson Family, Women's Studies

To link to this article: https://doi.org/10.1080/00497878.2020.1864372

曲 Published online: 14 Jan 2021.

Submit your article to this journal $\asymp$

Q View related articles $\widetilde{ }$

View Crossmark data $־$ 


\section{"Invisible, as Music - ": Sheet Music and Communication in the Dickinson Family}

Samantha Landau (D)

The University of Tokyo, Komaba

Music was a form of communication for Dickinson, both separate from and contained within her poetry. This paper will address how her usage of song stemmed from her frequent engagement with music in her life, inquiring beyond Dickinson's usage of song in her poems to the music and musicians that inspired her. It will primarily build upon the works of Carolyn Cooley, Carlton Lowenberg, Judy Jo Small, Jay Leyda, and Richard Sewall, among others, whose work on Dickinson's relationship with music has formed the basis for scholarship on the subject. Further, it will provide a counterpoint to George Boziwick's research into Dickinson's interest in popular tunes and Victoria Morgan's work on hymnody, in that its focus will be primarily classical music. Much of this research depends upon making deductions and identifying information from mostly uncollated diaries, sheet music, letters, and book manuscripts such as those found in the Martha Dickinson Bianchi collection at Brown University, which have been little-discussed in Dickinson studies. Martha Dickinson Bianchi was Emily Dickinson's niece; her mother, Susan, was Dickinson's best friend. Martha was responsible for continuing the editing and publishing of Dickinson's poetry in her own fashion, important work that her mother, Susan, had started after Dickinson's death in 1886. Martha also published articles about Dickinson's poems and letters, and memoirs of her interactions with Dickinson. The Martha Dickinson Bianchi collection contains a plethora of objects, including diaries, drafts of manuscripts, and an immense amount of sheet music. Of particular interest are the handwriting and markings on the sheet music, as well as the music itself, which aid in dating the pieces and identifying their owners. These dates and identifications allow scholars to verify to some degree how many people had access to the music stored at the Evergreens, ${ }^{1}$ and what time period this access covered. Further, the sheet music provides evidence to support the theory that the Dickinson family used music in their interactions, both in larger social contexts such as parties and visits from

CONTACT Samantha Landau this.elegy@gmail.com Department of English Language, Center for Global Communication Strategies, The University of Tokyo 3-8-1 Komaba, Meguro-ku, Tokyo 153-8902 Japan.

${ }^{1}$ The Evergreens is the name of house that Dickinson's brother, Austin, had built after his marriage to Susan Gilbert Dickinson. It is located close to the Dickinson Homestead; there is a small path that goes between the houses, which occupants used for frequent visits. For more on the provenance of The Evergreens and its ownership, see Barton St. Levi Armand, "The Keeper of the Keys: Mary Hampson, the Evergreens, and the Art Within." See also Christopher Benfey, "'Best Grief Is Tongueless': Jerome Liebling's Spirit Photographs."

(c) 2021 Taylor \& Francis Group, LLC 
friends, and in more intimate contexts, such as Susan Dickinson and Emily Dickinson contributing to Martha Dickinson Bianchi's music education. The Evergreens and the Dickinson Homestead (where Dickinson lived) were built close enough together that if the windows were open, whatever music was being played in the Evergreens might have been heard in the Homestead, and vice versa. The contents of the archive aid us in imagining the soundscape of the Dickinsons' lives and how that soundscape changed across their lifetimes. These archival collections also indicate that Dickinson's interest in music was not limited to popular music and hymn, but likely extended to classical music in ways that scholarship heretofore has not explored in depth. Overall, it demonstrates that music represented a form of communication for Dickinson that performed a complimentary role to her use of poetry: from birdsong to chorus to piano tunes, these melodies transmitted emotion and sound beyond the limits of verbal ability.

\section{Perspectives on Dickinson and music}

Music in Emily Dickinson's life clearly has many facets and meanings, not the least of which was how she used music to interact with those around her, especially her niece, Martha, and her sister-in-law, Susan. These interactions have been noted by Martha Dickinson Bianchi and Mabel Loomis Todd (who edited the first edition of Dickinson's poems and was her brother's mistress) as well as other contemporaries, and by subsequent generations of scholars. In addition to parlor music that Emily, Susan, and Dickinson's sister, Lavinia, would have engaged with, many oft-quoted materials remind us that Emily also discussed or played music more seriously: that of her correspondence with her friend Abiah Root and brother Austin, her strange musical dialogue with her cousin, John Graves, and that of her requests later in her life to hear Clara Newman and Mabel Todd sing and play the piano. These episodes are recorded in Jay Leyda's The Years and Hours of Emily Dickinson or scattered among Dickinson's letters, and frequently cited in existing scholarship when Dickinson's musical interests are discussed. For example, Caroline Cooley explains how Dickinson in her early years, classmates such as Abiah Root, and her Aunt Lavinia, seem to be influences on developing her talent. ${ }^{2}$

During her time at Amherst Academy, she used her piano in a lively rivalry over musical ability with Abiah Root. In 1845, she wrote to Abiah:

Are you practicing now you are at home - I hope you are, for if you are not you would be likely to forget what you have learnt. I want very much to hear you play.

\footnotetext{
${ }^{2}$ Aunt Lavinia is not to be confused with Dickinson's younger sister Lavinia. Aunt Lavinia wrote Edward Dickinson, Emily's father: "She has learned to play on the piano - she calls it moosic" (qtd. in Sewall 324). Her time at her aunt's house, loving and calm in comparison to the prosaic Dickinson household, provided the perfect situation for her to see music as a sanctuary. Before the age of 3, it seems Emily had learned some piano, though it is unclear whether these were just a willful and childish plucking of the keys.
} 
I have the same Instruction book as you have, Bertini, and I am getting along in it very well. Aunt Selby says she shant let me have many tunes now for she wants I should get over in the book a good ways first (L7).

Now that Dickinson had a piano in her house, she could move ahead in competition and conversation on the topic of playing the piano. She mentions that she has procured the "Bertini" instruction book, a reference to the book A Progressive and Complete Method for the Pianoforte by Henri Jerome Bertini. It was a popular text for learning the piano during the mid-1800s. Carlton Lowenberg notes that Dickinson's Aunt Selby gave her piano lessons during the summer of 1845 , and from that point onward Dickinson became a pianist who could both learn pieces as written and improvise in performance (Musicians 33). ${ }^{3}$

Dickinson would be 14 years of age before her father would purchase a piano for her, the first time someone in her family paid serious attention to her talent. Buying a piano is always an investment, and Emily's father had hers made to specifications. Hers was a rectangular-shaped piano, of a type known as a square Pianoforte, ${ }^{4}$ with decorations in a Renaissance revival style. The legs are hand-carved with flowers and intricate patterns; the music stand, soundboard, and other visible parts are inlaid with ivy and flowers. ${ }^{5}$ Her piano itself tells us quite a lot about the kind of musician she aspired to become, and what her family thought of her musical talents. On one hand, as Richard Leppert points out, the acquisition of the piano fits with her father's stabilizing financial situation and rising fortunes:

To the Victorian bourgeoisie the domestic pianoforte was as essential as the dining room table-in an ideological sense perhaps more important; respectability demanded its purchase as a marker of family position and accomplishment. (153)

Dickinson's father, therefore, would likely have gone along with his 14-year-old daughter's request because it was part of establishing the family as members of the middle class. As Leppert rightly points out, then, the piano represented material wealth that had little to do with music (155). While this might have been true for Dickinson's father, for Dickinson, this was not likely the case. Making music and sharing music with others, as an immaterial and transcendent medium that allows

\footnotetext{
${ }^{3}$ Although Dickinson wrote to her friend less frequently after leaving Mount Holyoke Seminary, she continued to play piano for friends and family at home well into the 1850 s.

${ }^{4}$ Square pianos were immensely popular for making music in domestic settings from the $18^{\text {th }}$ century until the late 1880 s; they reached peak popularity in the U.S. as European technology was improved upon. Square pianos were replaced by the better-sounding and much improved technology of upright and grand pianos after the 1880s. For examples of square pianos and information about their history, see Michael Cole, square piano restorer and builder's website: squarepianos.com/square.html

${ }^{5}$ According to Harvard's Houghton Library, the piano was manufactured between 1845 and 1851 by Hallet, Davis \& Co. out of Boston. Houghton has a listing of the Dickinson family artifacts that includes this piano, but unfortunately no photographs feature the immense attention to detail present on the piano itself. It is a work of art in addition to being an instrument.
} 
communication without words, was likely her primary aim in convincing her father to buy the instrument. ${ }^{6}$

There is also further evidence that Dickinson's interest in music did not just extend to rivalries with her school friends and entertainment for her immediate family. Cooley also cites Dickinson's relationship with her cousin John Graves as important to the way she communicated through music with others. Not only did she share with him a love of piano, but music seems to have been central to their relationship. In a letter dated to 1853, she told her brother Austin that John had made her "an Aeolian Harp, which plays beautifully, alone, whenever there is a breeze" (L115). ${ }^{7}$ Although the few letters exchanged between the two that survive date from between 1853 and 1856, Sewall states that John came to visit one April, and that "she [Emily] and Sue and John were alone in the Pleasant Street house, and she recalls one particularly haunting memory of those days, or rather nights, when she entertained John (and woke up Sue) with her piano" (406). ${ }^{8}$

Music's social role in Dickinson's life is made clear by her music book, a book of sheet music that she had bound. George Boziwick's work focuses on this music book, a collection she put together between 1843 and 1851 . He asserts that this book explains the role of popular music in the relationship between the inhabitants of the Homestead and the Evergreens, and, by extension, many of the people in their social circles. From this book, we understand that while Emily did not often write about the music that she and her family would have performed for their guests when they came visiting, such episodes must have occurred, as they did in any 19th century middle class household (Boziwick 83-84). Martha Dickinson Bianchi's biography supports this assertion:

According to letters and diaries, as well as universal tradition, the Dickinson house was overflowing with callers, who often "remained to supper," guests who drove up from farther towns-equally welcome, expected or unexpected-to spend the night or for longer visits ... (Bianchi Face to Face 107)

Boziwick notes that about $75 \%$ of the music is piano music; although most of these are based on popular tunes, some of these are also from opera scores,

\footnotetext{
${ }^{6}$ This sort of communication may be read as a bucking of gender norms. While men's musical education usually focused on the theoretical, women's musical education was practical, aimed at bequeathing the female music student with "accomplishments" that would advance her socially rather than professionally or emotionally. Indeed, the emotional aspects of music learning were seen as dangerous; passivity and solemnity in performance were expected. For a general discussion of gender and sound production, see Leppert 67-70; for a discussion on gender and sexual expectations with regard to music performance and learning, see Leppert 153-160.

${ }^{7}$ In return, Emily made him wristlets, which his daughter fondly remembered in the 1950s (L137).

${ }^{8}$ In addition, their friendship seems to have been one of mutual understanding - John not only comprehended her morbidity and her musical talent, he felt that her community did not truly appreciate her (405). When John visited, Sewall claims that the pieces she played were of her own composition (407). This is one of several episodes that hints at Emily's music being as private a gift as her poetry, shared only with close and trusted friends. Yet after John's graduation and his appointment to a school in New Hampshire, little is known about what, if any, friendship they maintained.
} 
such as that of Bellini's Norma and Rossini's Tancredi (Boziwick 86). Several songs also are also mistakenly attributed to Beethoven, a composer whose works were popular with sheet music consumers at the time (Boziwick 86). But classical sheet music dating to the overlap between Emily, Susan, and Martha Dickinson's lives, including works by Beethoven, are really present in the Martha Dickinson Bianchi archive; they are not misattributions. Therefore, whether or not Dickinson chose real pieces by Beethoven for her bound music book, she likely would have heard them either at the Homestead or the Evergreens.

Perhaps as a reaction against musical education that emphasized the practical, Susan and Emily Dickinson envisaged music as part of a theoretical framework, which may have influenced the way they shaped Martha's musical education. Music as part of such a theoretical framework denied to women is hinted at in letters between Emily and Susan, in which Dickinson's fragments discuss the experience of both creating and listening to music. Leppert explains that music is both an activity of hearing and seeing, that music not only contains instructions for the creation of sound, but also a set of behavioral guidelines (64). But the sisters-in-laws' usage of a shared musical vocabulary becomes a reaction against these guidelines, the standard practices of their day, emphasizing difference and uniqueness instead of conformity and practicality. For example, in Open Me Carefully, a collection of Emily's letters to Susan, music becomes an expression of the individual and their emotional or spiritual state (which seems to be more of a classical theoretical approach to music, rather than one suited to the propriety and practicality expected of female performers). Martha Nell Smith and Ellen Louise Hart identify the "She" in this letter-poem fragment as Susan (77). ${ }^{9}$ Emily writes about Susan:

She did not sing as we did -

It was a different tune -

Herself to her a Music

As Bumble bee of June.

(Open Me Carefully L30)

The natural imagery here, like the bee, seems to signal Dickinson's belief that music is present in all living things, which hum and sing and grow, and that each has its own important sound. While "tune" does not only indicate classical music here, there are also other letters that provide further clarification. For example, L5 and L6 indicate that she studied at Mr. Woodman's singing school in Amherst, and Mount Holyoke had an instructor of music,

${ }^{9}$ Smith and Hart date this poem to the period after Susan and Austin moved to the Evergreens, and points out that the fascicle version of it "was entirely inked over" as if someone, perhaps Mabel Todd, did not want anyone to read it. See $76-77$. 
with whom Dickinson would have studied. ${ }^{10}$ George Sullivan Woodman was a student of Lowell Mason and set up a singing school in Amherst; Mason was a major influence in musical education for children during the mid-19th century and published many songbooks for both children and adults that included a wide range of secular and popular song. ${ }^{11}$ Indeed, instructors during the mid-19th century would have mixed classical, religious, and popular song in their lessons, and therefore Dickinson's formal music education would likely have included classical works. ${ }^{12}$ It is, however, difficult to gauge how far her formal education in classical music ranged, and how much of her knowledge was self-taught, acquired via listening to performances, or obtained from discussions with family and friends.

Judy Jo Small also supports the idea that beyond piano, singing was an important way to enjoy the company of others at school, quoting an anecdote from a classmate of Dickinson's, Amelia D. Jones (Mount Holyoke, Class of 1849). Amelia claims that she and Dickinson walked together far away from the school with their singing books, and then sang together in chorus joyfully, with their only audience a few farm animals:

... we opened the book and our mouths, drew the diapason stops of our vocal organs, and sang tune after tune,-long metres, short metres, hallelujah metres, et id omne genus, - chants, rounds, fugues, anthems, etc., etc., carrying two parts, and snatches three or four, as the score demanded .... We needed no plaudits, for we were a joy to ourselves. We had found a remedy for depression, repression, suppression and oppression, and no two maidens returned that day from openair exercises more exhilarated than we. (Jones, qtd. in Small 49)

Small asserts that Jones's comments "indicate something about the breadth of musical kinds sung in the singing schools" (227). I would go a step further to say this concretely demonstrates that Dickinson would not only have had a musical vocabulary, but she would also have taken great joy in sharing music with others for various purposes. Jones says that the music helped them escape "oppression." Perhaps music also functioned as catharsis for Dickinson, like poetry. Akin to the musical allusions in her correspondence with Susan, this scene suggests that Dickinson engaged with music as a subversive act, with similarities to her engagement with poetry. Her poetry's interplay with musical forms, rhythms, and imagery may be reexamined as an expression of the complimentary languages of music and poetry, as Dickinson uses both to escape the constraints of what she referred to as "prose," the strictures of expected and proper written forms.

\footnotetext{
${ }^{10}$ Charles R. Anderson and Judy Jo Small both point out that the word "glee" in Dickinson's poems sometimes functions as a double entendre, meaning both happy energy and a chorus. Glee clubs were (and are) a popular form of chorus, often formed at colleges and schools. See Anderson 23; Small 35.

${ }^{11}$ For some examples of the songs that the lessons included, see, Small n. 14, 227.

${ }^{12}$ Mason, in particular, would have been influential to this knowledge of music; his career focused on disseminating his ideas about music (especially religious music), working with professionals and amateurs, and creating opportunities for vocal music and general music education. See Wienandt vii.
} 
We see this vocabulary put to good use regarding various aspects of classical music; Dickinson again uses musical terminology in conjunction with summer, growth, and happiness, where "orchestra" describes the sounds of summer, and the lack of it describes the winter:

Her Memories like

Strains - Review -

When Orchestra is

dumb -

The Violin in Baize -

replaced -

And Ear and Heaven -

numb -

(Open Me Carefully L85)

The memory of music here is layered onto a memory of a classical concert: orchestra can only refer to a body of classical music and violins are usually classical instruments. Thus, even in this letter that Ellen Louise Hart and Martha Nell Smith date to the 1860s, Dickinson consciously used classical music as significant metaphor for memory and nature. I do not believe she would have done so if she were not exposed to a significant amount of classical music. The casual classical listener would not bother to compare an orchestra and the buzz-hum of nature. In this, perhaps Emily has more in common with the classical metaphors in used by poets such as Walt Whitman, who was familiar with classical works and used them in his poetry. $^{13}$

Finally, several scholars such as Cooley and Lyndall Gordon claim that Emily's dialogue with others on music during her later life, when she became increasingly reclusive, was a one-sided performance focused on classical piano music. This seems primarily based on two accounts, that of Clara Newman, and that of Mabel Todd. ${ }^{14}$ Lyndall Gordon states that Todd "played Bach, Scarlatti, and Beethoven, and sometimes she lifted her voice and sang" (202). The response to this sound was a silent thanks in the form of a glass of wine,

\footnotetext{
${ }^{13}$ For more about poets' usage of music and music's usage of poetry, see Lawrence Kramer, Music and Poetry: The Nineteenth Century and After. Kramer considers romantic poetry's musical connections, and $19^{\text {th }}$ century music's poetic basis. For information specifically on Whitman and music, see Kramer 223-26. Kramer claims that Whitman "attempt[s] to dissolve the boundaries between poetry and music by linking the two arts to a psychological rhythm" (223). He further asserts that the poet uses his "imagination to transform any natural sound into music" (224). This closely parallels what Dickinson does in her letters to Susan, uniting and conflating the buzz-hum of nature with instruments and singing.

${ }^{14}$ It has also been often repeated that Mabel Todd played piano for Dickinson late in Dickinson's life, and that Emily listened from the stairs. See, for example, Benjamin Lease 31; Cooley 9-10; Sewall 218. Cooley claims that Dickinson and Todd had a friendship "founded and nurtured on their mutual love of music" (9). Cooley repeats Todd's claim that the music she played for Emily was classical, mentioning the composers Beethoven, Bach, and Scarlatti by name.
} 
a flower, a piece of cake. ${ }^{15}$ Martha Dickinson Bianchi also states that Fred Bliss, Abiah Root's son, played for Emily when he came to visit her:

Fred Bliss (Abiah Root's son) was a musician of rare natural gifts, playing Beethoven's sonatas, Schubert's songs, Schumann and Chopin, or bits of oratorio and opera that flitted through his head and fingers by the hour. I well remember how the "Moonlight Sonata" sounded through the silence of the old house ... From the time he came to Amherst fit for college until his graduation in 1880, their friendship of music was unbroken, and as long as she lived he never returned to Amherst without playing for her. (Bianchi Face to Face 35)

Bianchi makes note of several such "friendships of music," some of them, like Fred Bliss, growing out of earlier musical conversations (here, with her friend, his mother, Abiah), and some acquaintances made later, like that of a Mrs. Dole:

Her friend, Mrs. Dole, well remembered still as an accomplished pianist of wide study, and taste respectfully alluded to as "classical," who often played in public for charitable objects under social wings, always enjoyed playing for Aunt Emily when the coast was clear of callers and the freedom of the house their own. (Bianchi Face to Face 35)

Like Fred Bliss, Mabel Todd, and Clara Newman, Mrs. Dole came to play for Emily, and it is clear from Bianchi's description that she was there to play only for Emily, since the house was "clear of callers" and "the house their own" to make music. The intimate setting of two people engaged in a musical conversation, one the listener and one the player, creates communication different from linguistic dialogue or poetry. Kramer asserts that music and poetry are complimentary in their roles, that "each art makes explicit the dimension that the other leaves tacit" (6). By this he means that music has an "inexact" and "non-predictative" meaning, a "unique suggestiveness," that is not only pre-verbal, it also rests on the replacement of language with musical sound (6). Musical communication requires no allusions, ironies, metaphors, or tropes; instead, it works using tension, non-verbal elicitation of emotion, a heightened consciousness evoked by musical notes, rhythm, tempo, and vibration. Rather than imply here that language is somehow reductive, I instead offer that music is another dimension of communication, one that could take place both privately and publicly, and particularly, one that would have been subversive for Dickinson to utilize in a theoretical manner rather

\footnotetext{
${ }^{15}$ Moreover, the story closely resembles that of one told by Clara Newman, Dickinson's cousin. Newman insists that although Dickinson at one time played piano well, her repertoire shrank to only a few tunes, and from there, only to listening to others play the piano from the staircase. She explains:
}

After she became more reclusive, and gave up the piano entirely, I had the pleasure of playing for her and quite often would come to me just some little word as, "Emily is tired, and the sweet voice in the parlor cannot speak to her alone," or "There's a voice in the down-stairs; I call but it does not answer." I answered the summons when I could, and never without some acknowledgment. Sometimes a flower on the piano stool, again a little plate of fresh cookies, or best of all, a word written out for me. (Newman qtd. in Sewall 272-3) 
than as an entertainment for others. It makes sense that she would employ her musical education to create opportunities for expanding her social interactions; Dickinson likewise explored other modes of self-expression and communication: gardening, baking, writing poetry and letters.

However, from anecdotal evidence, it might be impossible to draw a concrete conclusion about Dickinson's engagement with classical music, as there is no mention of what kind of songs these visitors were playing for her. It is also not possible to conclude the frequency with which she used music (like poetry) to communicate with others - unlike her letters, which leave the evidence of her using poetry as a mode of communication, there is no recording, written or otherwise, of these musical visits. But further examination of Martha's music and notebooks, and Susan's diaries at the Bianchi Archive at Brown University has yielded another side of the story entirely.

\section{Music from the Bianchi archive}

It is certain that Emily Dickinson's relationship with her niece, Martha, and her best friend, Susan, went beyond exchanges of letters, gifts, and poems - it also included music. These musical episodes form the background for my search, among the documents at the Martha Dickinson Bianchi archive at Brown University, most of which are in the form of sheet music, ${ }^{16}$ for the music that may have belonged to Emily Dickinson herself, or to Martha's mother Susan. Some of these correspond to the information already uncovered about the way Dickinson communicated with others through music, and some have opened a new realm of mysteries yet to be solved.

The oldest pieces are written for Spanish guitar, dating to the 1830s, but it is unclear from previous scholarship who among the Dickinsons could have played those pieces. ${ }^{17}$ Classical music in the collection dates from the $1860 \mathrm{~s}$; pieces for piano and voice begin to appear in the early 1880s. It is possible that some or all of these pieces were played by or for Emily, with the pieces for classical piano being the most likely candidates. But little physical evidence, if any, such as handwriting or bills of sale, remain. The easiest way to

\footnotetext{
${ }^{16}$ Sheet music usually refers to music sold as a single song (sometimes part of a series). During the 19th century, it differs from what were known as "song sheets," which were usually only a single sheet of paper with the lyrics of a printed on it. Sheet music popularly circulated because it was cheap to print and distribute and also because it was easy for the musician to use to create their own personal bound music book, incorporating various types of music ranging from classical to popular. Dickinson and the women in her family all bound their own music in this way. For more on the bound music book belonging to Emily, see Boziwick, "Emily Dickinson's Music Book: A Performative Exploration," especially 83-89. Boziwick also reveals that Emily's musical communication also occurred in her relationship with her brother, Austin, as he would procure music for her to play when he traveled to large cities such as Boston (89).

${ }^{17} \mathrm{I}$ am a classically trained vocalist and a pianist and have also played the flute (solo and orchestral), but have only recently started learning guitar. At the time I visited the archive, I did not play guitar at all, and so could not determine the level of difficulty with any certainty. The age and type of these guitar tunes might be of interest to scholars working on guitar music and its history.
} 
identify who the music belonged to, then, is simply to read the name written on the verso and identify its handwriting; most of the archive's music has these identifying features in either Susan's or Martha's hand. The music dating to after Emily's death, starting in the late 1880s, increases greatly in technical difficulty, as does the amount of music purchased outside of Massachusetts, especially that of Russian composers. Opera scores begin to appear, dated in the 1890s, coinciding with the point when Martha went to study music in New York City, and increasing in number as she traveled to Europe for further study.

Several scores are written in Martha's own hand, some of these settings of her own poetry, or others' poetry. Scores for popular tunes and art songs dating from the early 20th century to the mid-20th century form the rest of the collection. It should be emphasized that none of these are collated into a particular box, nor are all of them dated; those with markings in pencil or pen primarily consisted of fingerings and dynamics, or in Susan's or Martha's handwriting, a name on the verso. Several pieces of interest dating from the 1870s and 1880s have unidentifiable handwriting that might belong to Emily herself; I would suggest, based on Bianchi's memoir, that it is possible Emily wrote notations on the music to guide Martha's playing (see quote below). It is also possible Emily herself had played some of these pieces, but this remains unclear. ${ }^{18}$

As anyone who has multiple family members or generations in the same house playing musical instruments (especially piano) knows, sheet music tends to pass from individual to individual, and becomes intermixed as a result. The Martha Dickinson Bianchi collection is no exception. The jumble therefore represents how music connected both the Dickinsons and their friends: entertained them, enlightened them, inspired them, and comforted them. The range and variety speak to the diverse uses of the music. In this collection, we can find music sourced from as close as Boston and as far away as Moscow. There are a great number of works published in Russia, in the original Russian editions, as well as editions from France, Germany, Austria, and Britain. As previously mentioned, classical music editions were not as available in the U.S. during much of the 19th century, and publishers were often unreliable in their attributions (as with the misattributed Beethoven pieces in Dickinson's music book). These issues must have lead Martha, Susan, and perhaps even Emily to source their music from importers or to write away for it from foreign publishers. Some of the music might have been procured on Susan and Martha's trips to Europe, a possibility indicated in Susan's diary entries from their trips.

\footnotetext{
${ }^{18}$ Unfortunately, I could not, with any certainty, identify any of the handwriting as Emily's on my own. After sending images of the most likely candidates to manuscript scholars and the Dickinson Museum, I was told that none of those were likely to be Emily's handwriting. They were most likely written by a young Martha whose handwriting somewhat resembles Dickinson's when written in haste.
} 
Perhaps one of the reasons for the fading of Dickinson's musical dialogue with John Graves was also that she began one with Susan. The evidence for this is visible in Martha's books as it is in the happenings of the Dickinson household. Bianchi writes in Emily Dickinson: Face to Face that Susan did not play piano as well as Emily but loved it just the same: "And music - though she herself did not play as well as Emily - what would Susan not commit or leave uncommitted for the sake of it!" (159) Bianchi describes how her mother would play piano for the children of the Sunday School at her church and teach them Christmas carols (154) and discussed music with their church's organist (159). It seems clear that Susan's engagement with music was also a dialogue with her community, both religious and secular, and with her family. Further, Martha attests that her mother and aunt also watched over her development as a young pianist:

Then, when her own little girl began taking piano lessons, how their excitement increased from the first piece of "sheet music" to the first movement from a Beethoven sonata, and how Emily characterized the difference from the book of "Selections" set before her own childish fingers! (Bianchi Face to Face159)

This passage clearly shows that Martha had better access to classical music than her mother and aunt. During the latter part of the 19th century, classical sheet music from Europe became more readily available for amateur musicians and music students. This was bolstered by a burgeoning music-printing business in the United States. Martha would have had the advantage of access to both European and American music. ${ }^{19}$ Moreover, she implies here that both of the women had an active role in her musical education, that they were shaping Martha's future music interests together. This mention of a mutual interest in nurturing Martha's musical talent is one of the reasons the Bianchi archive is such a valuable resource. In addition to providing material evidence, in the form of sheet music, that the Dickinson family spent considerable time sharing musical interests, through the markings on the music it is possible to see how closely Susan watched over her daughter's burgeoning talents - many of the sheets dating to the 1800s have Susan's handwriting on them. Although there are only faint and unconfirmed possibilities of written evidence that Dickinson was also involved in this education, surely the daily nature of music-making (as second nature to them as eating a meal) would have meant it would be left unmentioned, except tangentially.

Despite this description of an aunt and mother clearly invested in the musical education of their niece/daughter, the Bianchi archive today is an

\footnotetext{
${ }^{19}$ Sheet music, as opposed to music sold already bound as books, dominated the U.S. market before the advent of strict copyright controls for music publications. It is not a coincidence that I discovered most of the Bianchi archive at Brown to be comprised of unbound sheet music, and that the archive included quite a lot of popular song, the sort that Tin Pan Alley publishers specialized in; this type of music would have been common not only for music students during Dickinson's lifetime, but throughout Martha's as well.
} 
impossible jumble, an amalgamation of music dating as early as the $1830 \mathrm{~s}$ and continuing well into the 20th century. It is not lovingly kept as was Emily's music binder, but was passed along and preserved as a body of music to which no fewer than six or seven individuals contributed. Sheet music owned by Susan and Martha are clearly present, as are sheet music gifts to Martha (from friends such as Tod Galloway). Sheet music belonging to Alfred Leete Hampson and his wife Mary Landis Hampson is also mixed in (Alfred was a tenor and his wife seems to have enjoyed playing both classical and popular tunes, to interpret from the music with her name written on the verso). Alfred worked as Martha's secretary for many years, and was willed the Evergreens after her death; for that reason, it also appears that he inherited her collection of music. ${ }^{20}$ For the purpose of this essay, which is to assert that music was a mode of communication between the Dickinson family members, especially Emily, Susan, and Martha, we shall set aside these other interesting artifacts in the archive for future research.

Most of the classical music in the archive clearly belongs to Martha, and one might claim that Emily had little to do with her choice of songs. But Martha herself asserts that her aunt influenced her choices of music:

She was interested in my music, acting quite rapt as I played my simple little pieces to her, all the way up to Mendelssohn and Beethoven ... I took my favorites over now and then to stroll beneath her window, where she examined them through a swiftly drawn blind, reserving her decisions until I saw her next. (Bianchi Face to Face 33)

Not only did she play for Susan and Emily and receive their tutelage on her piano, she allowed her aunt to choose some of her music for her. Evidence for this might also be present in the archive. Starting after the early 1870s, when Emily might (or might not) have heard Anton Rubinstein play, there is a very clear increase in classical sheet music in the collection; in fact, there is a huge increase in the number of songs composed by Rubinstein in the collection after that date.

The search for music that the three women might have shared occupied my time during my research at the archive, looking particularly for earlier music such as Beethoven or Mozart that form standard educational fare for pianists and, as previously stated, would have done during Dickinson's lifetime as well as Martha's early piano education. In addition, because Dickinson herself mentioned Anton Rubinstein in her letters, any pieces written by him or related to his works were subjects

\footnotetext{
${ }^{20}$ For a detailed account of how Alfred and Mary Hampson came to live in and care for the Evergreens, see Barton Levi St. Armand, "The Keeper of the Keys: Mary Hampson, the Evergreens, and the Art Within." However, St. Armand neglects to spend any length of time on Martha's music or on her Steinway grand piano, which evidence from the Bianchi archive indicates the Hampsons cared for and used after Martha's death and which, by Martha's own accounts of her musical career, was very important to her. For a brief description of Alfred and Mary's relationship with Martha, see also "Martha Dickinson (Mattie) Bianchi (1866-1943), niece" on the Emily Dickinson Museum website.
} 
of interest. ${ }^{21}$ There were several pieces by famous composers dated from the 1850s until the 1880s that fit the time period when both Emily and Susan Dickinson might have shared their music with each other, or, later, during the 1870 s to 1880 s, contributed sheet music to Martha's music studies. In particular, the Beethoven sonata referenced above by Martha in Face to Face may be the music for Sonata Op. 57, which shows two or three sets of handwriting, one illegible and one very neat (Martha Dickinson Bianchi Archive Box 152). In the same box, there is a very worn arrangement for four hands of Beethoven's Op. 20, "Septett" [sic; it should read "Septet"], which looks to be an early Edition Peters from the typeface. This is a piano arrangement of a chamber music piece for winds and strings. Because it is arranged for four hands, it was meant to be performed by two people; some combination of family members or friends would likely have played this song together. Its worn state indicates it might have been a favorite, performed for guests or to pass the time. It also indicates that it might have been passed from an elder generation (Dickinson, her sister, and sister-in-law) to a younger generation of family members (Martha and her siblings). "Septet" is Beethoven at his most pleasing and calming: the song features scales, chords, and harmonies with very little dissonance that travel to melodic resolutions mainly resting in its $\mathrm{E}$ flat major key with very little dalliance into its relative or parallel minors. It also matters that Dickinson might have played this piece, or at least enjoyed listening to it, because it shows the household had an interest in standard Beethoven compositions extending beyond piano sonatas to chamber music (however arranged for piano). Finally, a Beethoven piece entitled "Marche Funèbre" from a set called "Beauties of Mozart and Beethoven" seems to have "Emilie" written on the verso (it is ripped, so indistinct) (Martha Dickinson Bianchi Archive Box 100). The style of this cover is much older, akin to the Spanish guitar music and unlike the music from the 1890s. Hidden among folders containing other music from the 1870 s and 1880s, this particular Beethoven also has the phrase "heavy \& high" written at the top of each page in what looks to be Emily Dickinson's own hand. It is likely this handwriting belonged to Martha Dickinson, and not to her aunt, but the resemblance is striking. This same handwriting appears in another piece in the folder, Carl Maria von Weber's

\footnotetext{
${ }^{21}$ Small notes that while Rubinstein's tour and music made a deep impression on Dickinson, the dates of his tour coincide with a point in her life when she was no longer traveling, and so could not have attended the concert. It is more likely, Small claims, that Dickinson heard about the concert from friends or relatives who did attend. According to R. Allen Lott, Rubinstein did perform as close to Dickinson's home as Springfield on October 21, 1872 (303). But we currently have no evidence that she attended a concert herself. Further attention is needed to the Rubinstein sheet music in the collection to ascertain whether these songs also provided Dickinson with an avenue for understanding the greatness of Rubinstein's music, if only secondhand through arrangements played by others, possibly including her niece. For connections between Rubinstein and Dickinson, see Small, 50-51 and n. 20 228. For information on Rubinstein's 1872-3 tour, see Lott, "Anton Rubinstein in America (1872-1873)."
} 
"Perpetuum Mobile" (Piano Sonata No. 1 in C Major, Op. 24). As discussed in the previous section of this essay, composers like Beethoven and Scarlatti have been noted previously in Dickinson scholarship. However, von Weber's name has not. This is strange because Dickinson's music book contains a piece identified by Houghton Library as composed by von Weber: "Von Weber's Last Waltz." This piece, however, is not actually by von Weber; Houghton has mis-identified it. $^{22}$ It was composed by Carl Gottlieb Reissinger and is a waltz in a style similar to some of the other music in Dickinson's bound music book. It is not similar in style to "Perpetuum Mobile" and it would be hard to confuse the two composers' styles if their pieces were heard in succession. The existence of the "Perpetuum Mobile" in the archive as well as the markings on it warrant further inquiry, especially considering the piece is more technically difficult than Beethoven's "March Funèbre" or "Septet" and requires not only dexterity of hands and fingers, but also strong working knowledge of scales and dynamics, and an ability to play complex passages quickly and cleanly. "Perpetuum Mobile" is not a piece for a pianist accustomed to playing simplified popular tunes, hymns, or choral accompaniments; it is a piece that demonstrates a strong command of the instrument and a knowledge of music theory to buttress those skills, and very likely indicates a commitment to hours of practice to learn to play the piece. Whoever played this piece, whether it was Martha, her mother, or her aunt, was an accomplished musician.

Pieces dated to just after Emily's death from other boxes show a deep interest in the compositions of Arthur Rubinstein. Of the numerous Rubinstein pieces in the archive, some are of special interest because the sheet music was published around the time Dickinson mentions Rubinstein's American tour (1872-3). One particularly heavy with markings (a sign that it was closely studied by Martha and perhaps also other family members), is a piano-only setting of one of his Lieder pieces indicated as Op. 117 No.1 arranged by Carl Albert Loeschhorn (also spelled Löschhorn). Though not indicated on the sheet music, this piece appears to be a reworking of Rubinstein's lieder piece "Sehnsucht" (Yearnings), from the set 6 Songs Op. 8 No. 5, written in $1850 . .^{23}$ Though today Rubinstein is probably best known for his founding of the Imperial Conservatory in St. Petersburg and his instruction of Pyotr Ilyich Tchaikovsky, in the 1870s, Rubinstein's compositions probably paralleled the fame of those of his contemporaries, Frédéric Chopin

\footnotetext{
${ }^{22}$ According to Lodewijk Muns, this misidentification is actually an error that goes back to von Weber's lifetime. See: lodewijkmuns.nl/2018/05/07/that-wild-waltz-of-von-webers/.

${ }^{23}$ Another curious Dickinson-Rubinstein connection here is that this piece dates to around the time Rubinstein became acquainted with Jenny Lind, the opera singer that Dickinson so admired, and composed several series of art song cycles. 1850 is also around the time that Lind toured the U.S. Perhaps this piece was chosen not only for its technical difficulty but also because it put the listeners in mind of a concert they wanted to remember.
} 
and Franz Liszt. ${ }^{24}$ However, by comparison, he was considered the lesser composer by many; Rubinstein was better known for his concert performances and contributions to Russian music education. It is curious then that the archive contains a surfeit of Rubinstein and a dearth of Chopin and Liszt. Did Martha decide to play these out of interest, or because she missed her beloved aunt?

At the outset of the archival research, my research question focused on whether the sheet music present in the Martha Dickinson Bianchi archive was a conglomeration originating in both the Homestead and the Evergreens, and played by Emily, Susan, Martha, and perhaps even Lavinia Dickinson. My discoveries supported my central thesis developed from anecdotal evidence that Dickinson did use music as another way of engaging and communicating with the women around her, which in turn likely influenced her use of musical language in her poetry and letters. The subversive nature of her use of music both as a musician and as language in her poetry indicates that music was an important method of self-expression for her. Further research is warranted in the archive to produce other conclusions, such as to what extent Susan Dickinson steered Martha toward a career in classical music and whether Emily Dickinson was involved at all in that stewardship. This would require indepth comparisons of dates and pieces, examinations of the markings on the music, and cross-referencing with other miscellany like diaries, journals, and notes that might provide clues to the ownership of the music. Yet the collection itself seems to provide enough evidence to assert that Emily's musical education as well as her conversations about music with others contributed both to her niece Martha's early encounters with classical music, especially at a time when Martha would have needed to decide whether to become quite serious about the piano or not. Emily's musicality included a knowledge of popular pieces from her youth and adulthood, and an ability to improvise both singing and on the piano. She and Martha also shared this love of music beyond genre. As Gerard Holmes, George Boziwick, Judy Jo Small, Carolyn Cooley, and others have established with their research, popular song was an integral part of the soundscape of the Homestead and the Evergreens. But the contents of the Martha Dickinson Bianchi archive insist to us that classical music was also part of a broader narrative of musical communication shared by Martha, Susan, and Emily, and their friends and family. Susan described Emily's writing after her death as "her swift poetic rapture the long glistening note of the bird one hears in June woods at high noon," that she (Emily) was like the "Martyrs who sing while they suffer" (Bianchi “The Unpublished Letters"). Even Susan's elegies for Dickinson imply a communication "invisible, as music" that haunts their correspondence and their legacy in Martha, stirring the reader to imagine the real

\footnotetext{
${ }^{24}$ For discussions on Rubinstein in comparison to his contemporaries, his students, his contributions to music education, and how he fit into the larger context of the development of Russian, German, and French classical music during the $19^{\text {th }}$ century, see Philip S. Taylor, Anton Rubinstein: A Life in Music.
} 
songs that must have inspired unspoken ways of conveying affinity, comfort, and emotion.

\section{Funding}

This work was supported by Showa Women's University; The University of Tokyo.

\section{ORCID}

Samantha Landau (D) http://orcid.org/0000-0003-1052-9832

\section{Works cited}

Anderson, Charles R. Emily Dickinson's Poetry: Stairway of Surprise. Holt, 1960.

Benfey, Christopher. "Best Grief Is Tongueless': Jerome Liebling's Spirit Photographs.” The Dickinsons of Amherst, edited by Christopher Benfey, Polly Longsworth, and Barton Levi St. Armand, UP of New England, 2001, pp. 169-209.

Bianchi, Martha Dickinson. "The Unpublished Letters of Emily Dickinson: Chosen and Arranged by Her Niece." The Atlantic, Jan. 1915, theatlantic.com/magazine/archive/1915/ 01/unpublished-letters-of-emily-dickinson/528909/. Accessed 25 Nov. 2020.

- Emily Dickinson Face to Face. Houghton Mifflin Company, 1932.

-. Archival papers 1834 - 1980. Boxes 97, 98, 99, 100, 101, 102, 202, 213, 145, 146, 147, 148, 149, 150, 151, 152, 153. John Hay Library, Brown U, Accessed 29 Aug. 2016 - 2 Sept. 2016.

Boziwick, George. “Emily Dickinson's Music Book: A Performative Exploration.” The Emily Dickinson Journal, vol. 25, no. 1, 2016, pp. 83-105. doi:10.1353/edj.2016.0005.

Cole, Michael. "Square Pianos." Michael Cole: Harpsichord and Pianoforte Maker, 2015, squarepianos.com/square.html. Accessed 25 Nov. 2020.

Cooley, Caroline. The Music of Emily Dickinson's Poems and Letters. McFarland, 2003.

Dickinson, Emily. The Poems of Emily Dickinson, edited by R. W. Franklin, Reading ed., The Belknap P of Harvard U, 1999.

- The Letters of Emily Dickinson. edited by Thomas H. Johnson, vol. 3, 1958, The Belknap P of Harvard U, 1986.

Gordon, Lyndall. Lives like Loaded Guns: Emily Dickinson and Her Family's Feuds. Penguin Books, 2010.

Kramer, Lawrence. Music and Poetry: The Nineteenth Century and After. U California P, 1984.

Lease, Benjamin. Emily Dickinson's Readings of Men and Books: Sacred Soundings. Palgrave MacMillan, 1990.

Leppert, Richard. The Sight of Sound: Music, Representation, and the History of the Body. U California P, 1993.

Lott, R. Allen. “Anton Rubinstein in America (1872-1873).” American Music, vol. 21, no. 3. Nineteenth Century Special Issue (Autumn 2003), pp. 291-318. JSTOR, jstor.org/stable/ 3250546. Accessed 29 Nov. 2020. doi:10.2307/3250546.

Lowenberg, Carlton. Emily Dickinson's Textbooks, edited by Territa A. Lowenberg and Carla L. Brown, West Coast Print Center, 1986.

-. Musicians Wrestle Everywhere: Emily Dickinson and Music. Fallen Leaf P, 1992. 
“Martha Dickinson (Mattie) Bianchi (1866-1943), Niece." The Emily Dickinson Museum, emilydickinsonmuseum.org/martha-dickinson-bianchi-1866-1943-niece/. Accessed 29 Nov. 2020.

Mason, Lowell. Musical Letters from Abroad. 1854. Da Capo P, 1967.

Miller, Cristanne. "Dickinson's Structured Rhythms." A Companion to Emily Dickinson, edited by Martha Nell Smith and Mary Loeffelholz, Wiley Blackwell, 2014, pp. 391-414.

Muns, Lodewijk. "That Wild Waltz of Von Weber's." Lodewijk Muns: Musicologist, Author, Musician, 7 May 2018, lodewijkmuns.nl/2018/05/07/that-wild-waltz-of-von-webers/. Accessed 29 Nov. 2020.

"Pianoforte; Renaissance revival square piano; floral and scroll carved legs and apron." Hallet, Davis \& Co., Boston, Massachusetts; Not before 1851, Dickinson Family Artifacts, Dickinson Room. Houghton Library, Harvard College Library. hollisarchives.lib.harvard. edu/repositories/24/archival_objects/735737. Accessed 26 Nov. 2020.

Sewall, Richard B. The Life of Emily Dickinson. 1974. Harvard UP, 1994.

Small, Judy Jo. Positive as Sound: Emily Dickinson's Rhyme. U Georgia P, 1990.

St. Armand, Barton Levi. "Keeper of the Keys: Mary Hampson, the Evergreens, and the Art Within." The Dickinsons of Amherst, edited by Christopher Benfey, Polly Longsworth, and Barton Levi St. Armand, UP of New England, 2001, pp. 107-67.

Taylor, Phillip S. Anton Rubinstein: A Life in Music. Indiana UP, 2007.

The Emily Dickinson Lexicon (EDL). Brigham Young U, 2007, edl.byu.edu/. Accessed 22 Mar. 2017.

"Von Weber's Last Waltz." Music: A Bound Volume of Miscellaneous Sheet Music, without Title Page/with Emily Dickinson's Name Written on Flyleaf]. Dickinson Family Library copy, EDR 469. Houghton Library, Harvard U, nrs.harvard.edu/urn-3:FHCL. HOUGH:10951150. Accessed 30 Nov. 2020.

Wienandt, Elwyn A. "Introduction." Musical Letters from Abroad, 1854. New York, NY: Da Capo P, 1967. Print. pp. v-xvi. 